\title{
BOOK REVIEW: PRINCIPLES OF CONTEMPORARY CORPORATE GOVERNANCE
}

\author{
David Brown*
}

Jean Jacques du Plessis, James McConvill and Mirko Bagaric Principles Of Contemporary Corporate Governance (Cambridge University Press, Melbourne, 2005) (395 + xxii pages)

Perhaps taking the Cadbury Report in 1992 as the starting date, ${ }^{1}$ there has been a growing body of articles, a small but increasing trickle of monographs, and a burgeoning volume of government initiatives around the world in relation to corporate governance, the latter especially in the postEnron environment. While the topic lends itself well to interdisciplinary scholarship, an academic lawyer's observation of the trend of books on the subject is that some would say that corporate governance has always been part of company law, and that there is nothing new about it. Thus, even recent texts in this part of the world, such as Austin, Ford and Ramsay, ${ }^{2}$ and to a lesser extent Farrar, ${ }^{3}$ tend to approach the subject as a subset of company law, particularly those parts of company law dealing with the relationship between shareholders and the board, and the duties of directors. The broader theoretical and policy approaches now being taken, however, call for an attempt to enunciate a framework of principles within which students and scholars can approach the subject, and policymakers and interested parties can operate. However, this is a "big ask". Therefore it was with eager anticipation that the title of this book enticed your reviewer between its covers. ${ }^{4}$

* Senior Lecturer, School of Law, Victoria University of Wellington.

1 Committee on the Financial Aspects of Corporate Governance Report of the Committee on the Financial Aspects of Corporate Governance (London, 1992).

2 R P Austin, H A J Ford and I M Ramsay Company Directors: Principles of Law and Corporate Governance (LexisNexis, Sydney, 2005).

3 John Farrar Corporate Governance in Australia and New Zealand (Oxford University Press, Melbourne, 2001).

4 Jean-Jacques du Plessis, James McConvill and Mirko Bagaric Principles of Contemporary Corporate Governance (Cambridge University Press, Melbourne, 2005). 
The book aims to "extract and evaluate the core principles". As is necessary with this subject, it begins with an explanation of the concept; yet immediately when introducing "principles" it resorts to lists provided by regulatory bodies and inquiries around the world, such as the King report in South Africa, ${ }^{5}$ and the Bosch reports in Australia. ${ }^{6}$ It goes on to provide a useful overview of the stakeholder debate, identifying who stakeholders are and what their role is argued to be. As one gets further into the book it descends to quite particular detail (through the use of lists) as to the content of Australian reform initiatives, taking one through a history of Australian reform proposals in various reports, for example Bosch, Hilmer, and the $\mathrm{HIH}$ reports. ${ }^{7}$ There is then a detailed discussion listing the principles in the ASX Principles and Best Practice recommendations, ${ }^{8}$ and a useful overview of initiatives in leading jurisdictions and that of the OECD. While there is much useful and well-collated material in these chapters, the "core principles" could have been extracted from these overlapping reports and regulatory statements, rather than leaving the readers to do the hard work of extracting them from the multiple lists in the different chapters. Furthermore, the initial chapter containing the discussion of why corporate governance matters could have benefited from mention of empiricial research about the link or non-link between good corporate governance and company performance, or bad corporate governance and insolvency.

In terms of the concentration on principles and concepts, the best chapters (especially for nonAustralians) are those on stakeholders, board functions and structures, and auditing and auditors (though not surprisingly this is within an Australian regulatory context of the Federal Government's CLERP 9 package). ${ }^{9}$ However, in discussing principles and concepts, the authors' firm views, for example, as to the over-exaggerated value of independent non-executive directors, permeate the work.

The book makes very extensive use of case studies, diagrams and pages copied from websites. This makes it a useful teaching tool. The real-life case study of the HIH insurance group collapse in Australia provides the backdrop for discussion throughout the book, particularly in the very detailed discussion of the use of civil penalties, and the more general comments on the topic in the Owen report. The chapter on ASX Best Practice makes extensive use of company website material, and provides a list of further websites. As illustrative tools they make the work more readable, particularly to students, but in the nature of online material, they will become quickly out of date as sources of information. However, the authors "strongly encourage readers to surf away" for

5 King Report on Corporate Governance (Institute of Directors in Southern Africa, Parktown (SA), 1994).

6 Business Council of Australia Corporate Practices and Conduct (Information Australia, Melbourne, 1991); the second edition was published in 1993, and the third in 1995

7 See du Plessis, McConvill and Bagaric, above n 4, 91, 97 and 284.

8 See du Plessis, McConvill and Bagaric, above n 4, 133 and following.

9 Du Plessis, McConvill and Bagaric, above n 4, chs 2, 3 and 10. 
themselves. (This should be distinguished from the other type of surfing popular in Australasia, the etiquette of which the authors later draw upon to develop their argument that social norms can form an effective self-regulatory framework in contrast to the post-Enron formalisation of corporate governance.) There is no doubt that the internet is becoming an important tool for investors and those who actively monitor companies' social and environmental performance, and a potentially important tool for shareholder activism, particularly through disclosure of information but also for voting.

The volume of Australian material makes this primarily an Australian resource, but, writing at a time when the New Zealand Securities Commission has just announced a closer cooperation with the Australian Securities and Investment Commission, ${ }^{10}$ the chapter on hard, soft and hybrid regulation, and on the (in the authors' view) less-than-perfect overlapping approaches of ASIC and the ASX, will be useful food for thought for New Zealand readers and policymakers. Furthermore, the endorsement of the role of Shareholder Committees will be welcome news to those at Fonterra and other New Zealand companies contemplating such a move.

There is no separate chapter in this book about corporate social and environmental responsibility, let alone the broadening debate about quadruple bottom line reporting. In chapter 2 the authors express the view that environmental law, labour law and consumer law are separate regulatory regimes which existed long before corporate governance came to the fore, and should be kept separate from it. The arguments in relation to corporate social responsibility are subsumed (or sidelined?) within a chapter on ethics near the end of the book, only to be rejected. This chapter does stand out from the rest of the book for its philosophical approach, drawing on the writing of Professor Bagaric in this area, who is well-known for his views on ethical issues. ${ }^{11}$ The authors' view is that the ethical duty of directors is to faithfully serve the interests of shareholders. The authors are consistently conservative. They clearly believe quite passionately in corporate governance, but come down firmly on the side of shareholder primacy. Furthermore, when looking to the future, they take the view, following others such as Ribstein, and Romano, ${ }^{12}$ that the reaction of regulators in Australia and the United States will be judged by history as an over-reaction, and that we will come to prefer informal norms and light self-regulation again.

In conclusion, the title of this book both understates and overstates what it does. It does contain principles of corporate governance, though they are not extracted for the reader, and from the point of view of a student of the subject it is doubtful if the book will have achieved its object of

10 Securities Commission "ASIC and Securities Commission to Increase Cooperation" (25 August 2005) Press release.

11 See for example Mirko Bagaric "A Utilitarian Argument: Laying the Foundation for a Coherent System of Law" (2001) 10 Otago LR 163.

12 See du Plessis, McConvill and Bagaric, above n 4, 364 and following. 
"demystifying" the subject. There are many "hot topics" that could have been explored, such as the debate about active and passive shareholders and institutional shareholders, and the application of corporate governance principles to state-owned entities or non-profit organisations. However, the title understates what the work is about, since it is also about the regulation and practice of Australian corporate governance, contains much useful source material on theories and approaches around the world and the practical working out of recent Australian governance issues (particularly $\mathrm{HIH}$ ), and is imbued throughout with the authors' views as to the scope and future of corporate governance regulation. The latter can be seen as a strength or a weakness, depending on the purpose for which one wishes to use the work, and whether one agrees with their views. Corporate governance is not so much a subject in need of "demystifying", but a subject which has to be seen as highly political. Therefore it is difficult, particularly when students are part of one's target audience, to steer a clear and neutral path through competing theories and agendas. In this respect it has to be acknowledged that the authors have explicitly nailed their colours to the mast. Nevertheless, in terms of its coverage and research of the subject and the wealth of practical detail, particularly in respect of Australia, this book has no competitor, and is a welcome and timely resource. 